Faculty of Agronomy and Veterinary Medicine, Ibn Khaldoun University, Tiaret, Algeria.

\title{
CONTROL OF OVARIAN ACTIVITY AFTER ESTROUS SYNCHRONIZATION WITH PRID, CRESTAR AND PROSTAGLANDINS AND AS MONITORED BY ULTRASONOGRAPHY IN DAIRY CATTLE IN WEST OF ALGERIA
}

(With 3 Tables and One Figure)

\author{
By \\ A. BENALLOU; SAMIA MELIANI; G. SAIDI* \\ and $A . N I A R$ \\ *Faculty of Sciences, Es Senia University, Oran, Algeria.
}

(Received at 4/3/2007)

مراقبة نشاط المبيض خلال عملية السيطرة على الثبق بواسطة وإنة

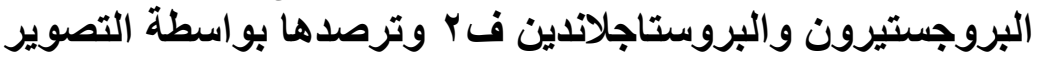

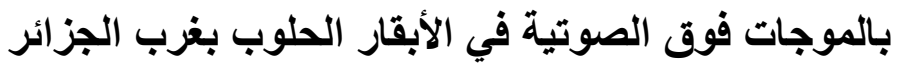

أبو عبدالله بن علو ، سامبة مليانح ، جمال سعيلى ، عبل اللطيف نيار

تمت هذه الدراسة على مجموعة من البقر الحلوب من فصيلة الهولثتاين ذي البقع السوداء

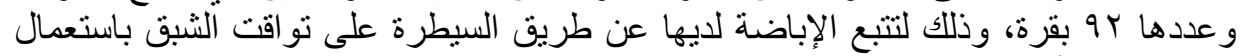

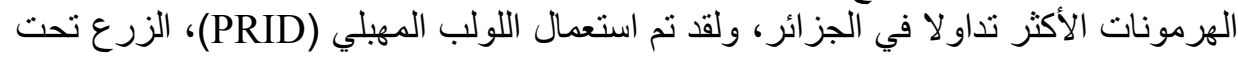

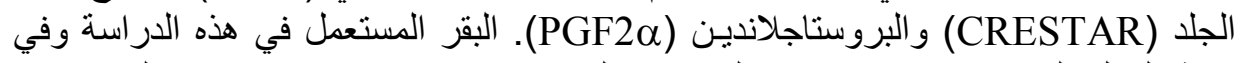

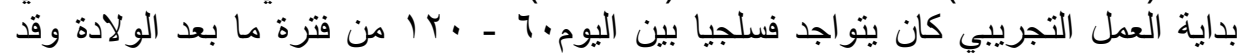

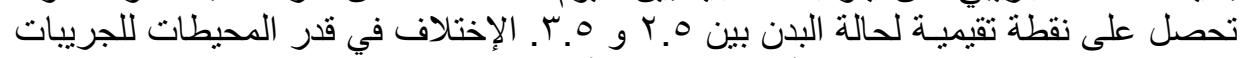

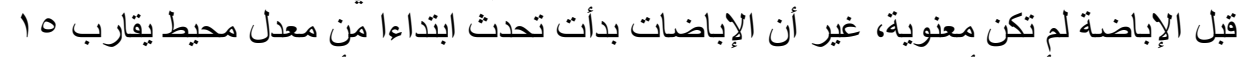

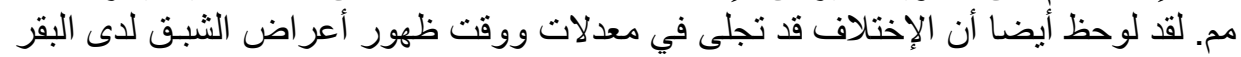

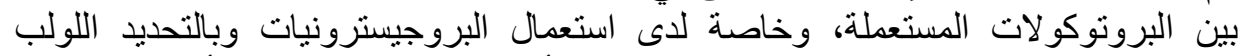

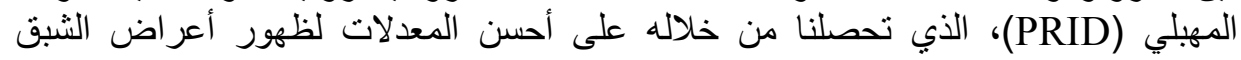

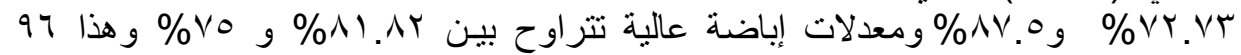

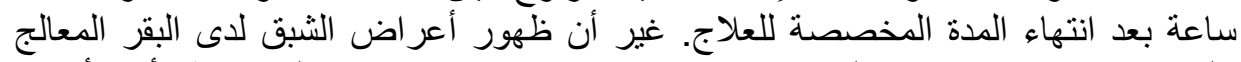

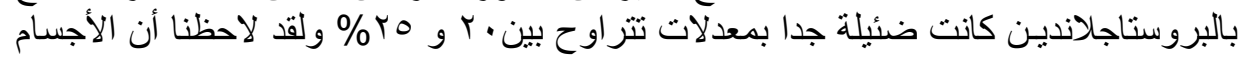

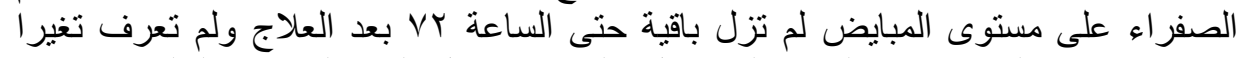

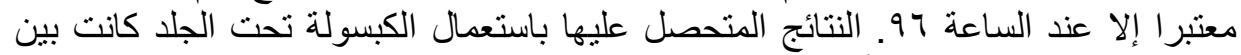

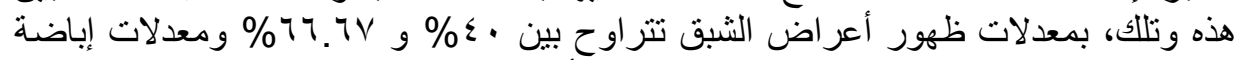

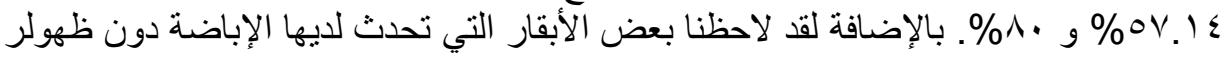




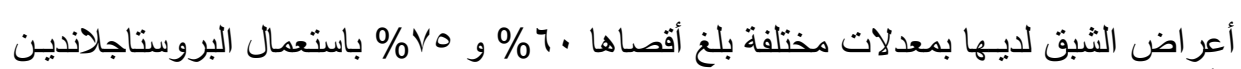

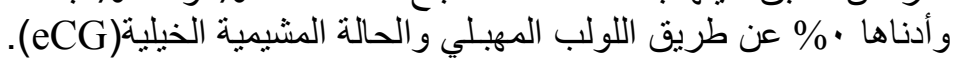

\section{SUMMARY}

Ninety two prim Holstein cows, from different dairy herds, were randomly assigned to progestin protocols (PRID or Norgestomet) or prostaglandin's, to synchronise estrous, according to the most used protocols in Algeria, in order to compare their efficiency on our dairy cattle. All cows were between day 60 and 120 post-partum at the beginning of the experiments, and at a score body condition between 2 and 3,5. The follicular diameters were not significantly different between treatments, whereas ovulations were observed around $15 \mathrm{~mm}$ of diameter. Results of estrous synchronisation were very different between treatments; treatment with the Intra Vaginal Device (PRID) provided better rates of estrous expression $(72,73 \%$ and $87,5 \%)$ and better ovulations rates $(81,82 \%$ and $75 \%)$ about $96 \mathrm{~h}$ post treatment. An intermediate rate was observed with Norgestomet protocols $(66,67 \%$; $40 \%$ and $42,86 \%)$ of animals in estrous, and $(77,78 \% ; 80 \%$ and $57,14 \%$ ) of ovulations. Bet, a lesser rate was observed with PGF2 $\alpha$ protocol (20 and 25\%) of estrous expression, rate of animals with retained corpus luteum, was very high and began to decline at $72 \mathrm{~h}$ after the second injection. In this study, some animals ovulated without expression of heat; the highest rate $(60 \%$ and $75 \%)$ was noted with prostaglandin's protocols, the intermediate results were observed with Norgestomet protocol $(22,22 \% ; 40 \%$ and $14,29 \%)$, and the lesser rate was noted with the PRID protocol $(9,09 \%$ and $0 \%)$.

Key words: Ovarian activity, estrous, prostaglandins, ultrasonography, dairy cattle

\section{INTRODUCTION}

Fertility of dairy cows is of growing concern. Reproductive indices that are used to assess reproductive management show a negative trend during the past decade despite increased knowledge and professional attention (Van Eerdenburg et al., 2002). Poor estrous detection is the major contributor to low fertility (Reimeirs et al., 1985). Until recently, it was generally believed that poor estrous detection was caused by the lack of commitment of the farmer, due to other priorities (Alexander et al., 1984). 
However; standing behavior is not observed in over $50 \%$ of cows estrous, in a number of herds, and no data are available to relate the moment of ovulation to other estrous symptoms (Van Eerdenburg et al., 2002).

Follicular size can be regarded as an indicator for functional capacity of the follicle. In these poor quality follicles, production of estradiol would be impaired resulting in lower expression of estrous behavior (Lyimo et al., 2000). According to Britt (1992), current fertility problems in dairy industry might be due to low quality of follicles and oocytes as a result of postpartum negative energy balance.

The keys to successful estrous synchronization are closely synchronized, rapid declines in circulating progestin concentrations and synchronous growth and ovulation of a viable follicle (Mapletoft et al., 2003).

Although current techniques for estrous synchronization with PGF2 $\alpha$ are successful (Odde, 1990; Larson and Ball, 1992), and variation in ovarian follicular wave dynamics results in poor synchrony of estrous and ovulation because induction of luteolysis when a dominant follicle is mature will result in estrous and ovulation in 2 to 3 days, whereas the interval will be much longer if another follicle must be recruited from a new follicular wave (Kastelic and Ginther, 1991).

Although follicular dynamics during the normal estrous cycle have been extensively studied as an adjunct to develop effective estroussynchronization strategies (Ireland et al., 2000), less information on post-partum follicular dynamics is available (Rajamahendran and Taylor, 1990; Savio et al., 1990). Moreover, the relationship between early follicular dynamics and subsequent fertility is not clear in modern dairy cows. Recently, it was documented that most cattle exhibit 2 or 3 follicular waves during the normal estrous cycle (Ireland et al., 2000).

The objective of the present study was to compare the effect of different treatments protocols on largest follicles, daily follicle diameters evolution, corpus luteum, the time of estrous and ovulation in postpartum imported prim Holstein dairy cows in Algeria.

\section{MATERIALS and METHODS}

Animals: 92 Cyclic Postpartum multiparous (3 to 6 years old) Prim Holstein imported dairy cows, with a score body of 2 to 3,5 (1-to-5 scale, $1=$ emaciated and $5=$ obese), with average milk production of $5185 \mathrm{~kg} / \mathrm{cow} /$ year, from ten private farms in Tiaret area (North west of 
Algeria), were assigned randomly to one of four treatments. Cows assigned to the prostaglandin $(\mathrm{PG})$ protocol $(\mathrm{n}=15)$ received a double injection of PGF2 $\alpha$ (ND Estrumate, $2 \mathrm{ml}) 11$ days apart. Cows assigned to prostaglandin eCG protocol $(\mathrm{PG}+\mathrm{eCG})(\mathrm{n}=10)$ received the same treatment with an injection of eCG (500UI) at the time of the second injection of PGF2 $\alpha$. Cows assigned to the first progesterone protocol, received a PRID ${ }^{\circledR}$ with the estradiol-17 $\beta$ capsule (CEVA Laboratories, France; $1,55 \mathrm{~g}$ of progesterone) for 11 days; the (PRID) group $(\mathrm{n}=11)$ do not received other treatments, the (PRID+eCG) group $(n=9)$ received an injection of eCG (500 UI) at the end of treatment (Fig. 1).

Cows assigned to the second progesterone protocol received an implant of Crestar ${ }^{\circledR}$ (Intervet, $3 \mathrm{mg}$ of Norgestomet) for 11 days with $5 \mathrm{mg}$ estradiol valerate in IM at the day of implant, the (CR) group $(n=15)$ do not received other treatment, the $(\mathrm{CR}+\mathrm{PG})$ group $(\mathrm{n}=16)$ received an injection of PGF2 $\alpha$ (ND Estrumate, $2 \mathrm{ml}$ ) $48 \mathrm{~h}$ before the end of treatment, the $(\mathrm{CR}+\mathrm{PG}+\mathrm{eCG})$ group $(\mathrm{n}=16)$ received an injection of PGF $2 \alpha$ (ND Estrumate, 2ml) $48 \mathrm{~h}$ before and an injection of $500 \mathrm{IU}$ of $\mathrm{eCG}$ at the end of treatment (Fig. 1).
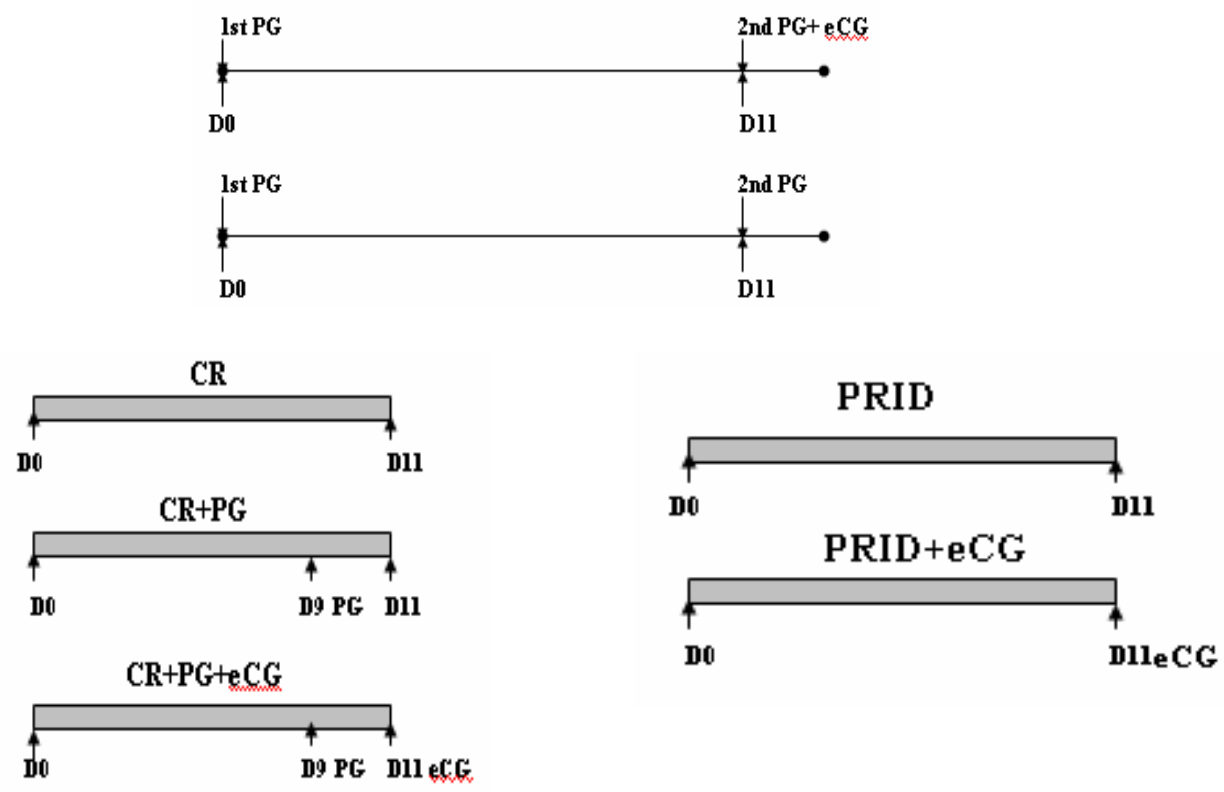

Fig. 1: Experimental design of treatment protocols, ultrasonography was performed every day for four days, and only diameters of dominant follicles were retained. 


\section{Ultrasonography, Estrous and Ovulation:}

All cows were examined daily by transrectal ultrasonography to record follicular development using a Pie Medical Falcon 100 equipped with a 6-MHz linear-array transducer (Pie Medical Falcon 100, Netherlands) all follicles $(\geq 10 \mathrm{~mm}$ ) were recorded. Cows were examined daily from D0 to D4 after treatment until ovulation. A dominant follicle was defined as a large follicle, with other follicles.

Ovulation was determined by the disappearance of a large dominant follicle from an ovary. The presence of a corpus luteum on ovaries was also recorded.

Measurements were made on a single frozen image of the apparent maximal area of each follicle or the corpus luteum, using the average diameter in two directions at right angles. Only follicles $\geq 10 \mathrm{~mm}$ were retained. Cows were observed for signs of behavioral estrous beginning 1day before and continuing for 4 days following the final PG injection or Progestin insert withdrawal (for both PRID and CRESTAR protocols). Visual observations to detect signs of estrous were carried out during 4 days following synchronization treatment.

Statistical Analysis: Effects of treatment on follicle size at the end of each treatment were tested by Fisher's least significant difference test.

\section{RESULTS}

Table 1: Mean follicular diameters as daily observed after the end of treatments with PRID, CRESTAR, PG and eCG.

\begin{tabular}{|c|c|c|c|c|c|c|c|}
\hline Item & $\begin{array}{l}\text { PRID } \\
(n=11)\end{array}$ & $\begin{array}{c}\text { PRID+eCG } \\
(\mathrm{n}=8)\end{array}$ & $\begin{array}{c}\text { CR } \\
(n=9)\end{array}$ & $\begin{array}{c}C R+P G \\
(n=10)\end{array}$ & $\begin{array}{c}\mathrm{CR}+\mathrm{PG}+\mathrm{eCG} \\
(\mathrm{n}=14)\end{array}$ & $\begin{array}{c}P G \\
(n=15)\end{array}$ & $\begin{array}{c}\mathrm{PG}+\mathrm{eCG} \\
(\mathrm{n}=8)\end{array}$ \\
\hline \multicolumn{8}{|l|}{ Days } \\
\hline D0 & $14 \pm 4,24$ & 12 & $15,71 \pm 2,98$ & $12 \pm 2,71$ & $16,25 \pm 2,06$ & $13 \pm 1,87$ & $13 \pm 3$ \\
\hline D1 & $14,91 \pm 3,33$ & $13,57 \pm 2,76$ & $17 \pm 3,07$ & $12,6 \pm 2,51$ & $15,8 \pm 3,7$ & $13,92 \pm 1,44$ & $15,67 \pm 1,53$ \\
\hline \multirow{2}{*}{ D2 } & $15,82 \pm 3,87$ & $13,86 \pm 2,91$ & $17,14 \pm 3,80$ & $13,8 \pm 2,05$ & $16 \pm 5,20$ & $14,64 \pm 1,86$ & $17 \pm 2,31$ \\
\hline & $14,2 \pm 1,48$ & $14 \pm 1,73$ & $15 \pm 4,24$ & $14,33 \pm 2,89$ & $15,75 \pm 3,5$ & $15,42 \pm 1,62$ & $16,5 \pm 0,71$ \\
\hline D3 & 15 & & $14 \pm 4$ & 16 & & $13,67 \pm 2,5$ & \\
\hline $\begin{array}{l}\text { D4 } \\
\text { Ovulation }\end{array}$ & $15,33 \pm 2,16$ & $15 \pm 2,97$ & $17,5 \pm 3,59$ & $14,2 \pm 2,49$ & $17 \pm 2,94$ & $14,9 \pm 1,79$ & $17,75 \pm 1,5$ \\
\hline $\begin{array}{l}\text { Evolution } \\
\mathrm{mm} / 24 \mathrm{~h}\end{array}$ & $0,87 \pm 0,06$ & $0,21 \pm 0,10$ & $1,24 \pm 1,28$ & $1,10 \pm 0,47$ & $1,15 \pm 0,21$ & $0,96 \pm 0,45$ & $2,00 \pm 0,94$ \\
\hline
\end{tabular}


Table 2: Percentage of cows observed in estrous and ovulated after the end of treatments with PRID, CRESTAR, PG and eCG.

\begin{tabular}{|c|l|c|c|c|c|c|c|}
\hline \multicolumn{2}{|c|}{ Days } & D0 & D1 & D2 & D3 & D4 & ALL COWS \\
\hline \multirow{2}{*}{$\begin{array}{c}\text { PRID } \\
(\mathrm{n}=11)\end{array}$} & Estrous \% & 0 & 0 & 27.27 & 45.45 & 0 & 72.73 \\
\cline { 2 - 8 } & OV \% & & & & 54.54 & 27.27 & 81.82 \\
\hline \multirow{2}{*}{$\begin{array}{c}\text { PRID+eCG } \\
(\mathrm{n}=8)\end{array}$} & Estrous \% & 0 & 0 & 37.5 & 37.5 & 12.5 & 87.5 \\
\cline { 2 - 8 } & OV \% & & & 12.5 & 50.00 & 12.50 & 75.00 \\
\hline \multirow{2}{*}{ CR (n=9) } & Estrous \% & 11.11 & 0 & 33.33 & 11.11 & 11.11 & 66.67 \\
\cline { 2 - 8 } & OV \% & & 11.11 & 0 & 55.55 & 11.11 & 77.78 \\
\hline \multirow{2}{*}{$\begin{array}{c}\text { CR +PG } \\
(\mathrm{n}=10)\end{array}$} & Estrous \% & & & & 40.00 & 0 & 40.00 \\
\cline { 2 - 8 } & OV \% & & & & 40.00 & 40.00 & 80.00 \\
\hline $\begin{array}{c}\text { CR+PG+ } \\
\text { eCG } \mathrm{n}=14\end{array}$ & Estrous \% & 14.29. & 0 & 0 & 28.57 & 0 & 42.86 \\
\hline \multirow{2}{*}{$\begin{array}{c}\text { PG }(\mathrm{n}=15) \\
\text { OV } \%\end{array}$} & Estrous \% & 6.67 & 0 & 0 & 6.67 & 6.67 & 20.01 \\
\cline { 2 - 8 } & OV \% & & 6.67 & 6.67 & 13.33 & 46.67 & 73.34 \\
\hline \multirow{2}{*}{$\begin{array}{c}\text { PG + eCG } \\
(\mathrm{n}=8)\end{array}$} & Estrous \% & & & & 25.00 & 0 & 25.00 \\
\cline { 2 - 7 } & OV \% & & & & 25.00 & 50.00 & 75.00 \\
\hline
\end{tabular}

Table 3: Percentage of cows with CL on ovaries after the end of treatments with PRID, CRESTAR, PG and eCG.

\begin{tabular}{|l|c|c|c|c|c|c|c|}
\hline Item & $\begin{array}{c}\text { PRID } \\
(\mathrm{n}=11)\end{array}$ & $\begin{array}{c}\text { PRID+eCG } \\
(\mathrm{n}=8)\end{array}$ & $\begin{array}{c}\mathrm{CR} \\
(\mathrm{n}=9)\end{array}$ & $\begin{array}{c}\mathrm{CR}+\mathrm{PG} \\
(\mathrm{n}=10)\end{array}$ & $\begin{array}{c}\mathrm{CR}+\mathrm{PG}+\mathrm{eCG} \\
(\mathrm{n}=14)\end{array}$ & $\begin{array}{c}\text { PG } \\
(\mathrm{n}=15)\end{array}$ & $\begin{array}{c}\text { PG+eCG } \\
(\mathrm{n}=8)\end{array}$ \\
\hline days & & & & & & & \\
D0 & 9,09 & 25 & 55,56 & 20 & 42,86 & 93,33 & 50 \\
\cline { 2 - 8 } D1 & 9,09 & 0 & 22,22 & 0 & 28,57 & 93,33 & 50 \\
\cline { 2 - 8 } D2 & 0 & 0 & 11,11 & 0 & 14,29 & 86,67 & 50 \\
\cline { 2 - 8 } D3 & 0 & 0 & 11,11 & 0 & 14,29 & 73,33 & 50 \\
\cline { 2 - 8 } D4 & 0 & 0 & 11,11 & 0 & 0 & 20 & 0 \\
\hline
\end{tabular}

\section{DISCUSSION}

Three cows (two from PG + eCG group and one from the PRID + eCG group) were excluded from this study, cows from the PG + eCG presented inactive ovaries, and the cow from the PRID + eCG group presented cystic follicles $(>25 \mathrm{~mm})$ persistent more than 1 week.

Six cows (two from the CR group, two from $\mathrm{CR}+\mathrm{PG}$ group and two from $\mathrm{CR}+\mathrm{PG}+\mathrm{eCG}$ group) lost their implants. In total five cows (three from $\mathrm{CR}+\mathrm{PG}$ group and two from $\mathrm{CR}$ ) didn't respond to treatments and presented inactive ovaries. Three cows (two from CR group and one from $\mathrm{CR}+\mathrm{PG}$ group) presented cystic follicles $(>25 \mathrm{~mm})$ persistent more than 1 week (Lucy, 2001). These cows were also excluded from this study. 
Totally, seventeen cows were excluded from this study. So, seventy five cows were retained.

\section{Follicular diameter}

The mean of follicular diameter didn't differ between treatments $(\mathrm{P}>0.10)$; however, follicular diameter varied from 12 to $17 \mathrm{~mm}$ (Table1). Follicles ovulation with prostaglandins based protocols was observed at a mean diameter of $14,9 \pm 1,79 \mathrm{~mm}$ with a mean evolution of $0,96 \pm 0,45 \mathrm{~mm} /$ day, which is comparable with results of SARTORI et al. (2002) 13,7 $130,3 \mathrm{~mm}$ Vs $15,8 \pm 0,4 \mathrm{~mm}$, and an evolution diameter of $0,8 \pm 0,1 \mathrm{~mm} /$ day $\mathrm{Vs} 1,0 \pm 0,1 \mathrm{~mm} / \mathrm{d}$ respectively; with SMITH and STEVENSON (1995), 16,4 $\pm 0,7 \mathrm{~mm}$; BRITO et al. (2002) $13,2 \mathrm{~mm}$ with a mean evolution of $1,02 \mathrm{~mm} /$ day. The injection of prostaglandins controls the lifespan of the corpus luteum but don't affect the follicular diameter so that the follicle continues to grow until estrous and ovulation and it can take from 2 to 4 days times necessary for requirement.

Custer et al. (1994) reported that the average diameter at ovulation is about $14 \pm 03 \mathrm{~mm}$ and $17 \mathrm{~mm}$; with a growth rate of $1,3 \pm 0.1 \mathrm{~mm} /$ day and $0.7 \mathrm{~mm} /$ day respectively for the PRID and CRESTAR; Same results have been reported by Smith and Stevensen (1995) for the PRID and CRESTAR (16.4 $\pm 0.8 \mathrm{~mm})$.

\section{Percentage of observed oestrous and ovulations}

For cows synchronized by prostaglandins, several authors have reported variable rates; Beal et al. (1983) reported a rate of $28 \%$ spread out over 7 days which is similar to that noted in our study (20 and 25\%). For Brito et al. (2002), the rate noted was of $36 \%$ (percentage of cows observed in heats at the end of 96h). On the other hand, a rate of $62 \%$ has been reported by Smith and Stevenson (1995). This will be explained by the fact that at the time of luteolysis, the dominant follicle had not yet completed its full development, and this which involve a spreading out of oestrous after treatment (Mialot et al., 1999; Driancourt, 2001). Otherwise, we have noted that $75 \%$ of ovulations have been concentrated between 48 and $96 \mathrm{~h}$ for cows treated by prostaglandins (Table 2).

The most important problem found with PGF2 $\alpha$ is the variability of the interval from injection to estrous (ODDE, 1990).

Luteal tissue and plasma progesterone concentration were reported to be highly correlated in heifers and cows (Spêecher et al., 1989; Kastlic and Ginther, 1990). Causes of luteolysis failure (occurring 
in $\geq 10 \%$ of the cows treated with prostaglandins) are not clear but may be related to several factors (Peters and Ball, 1995).

The rate of cows observed in oestrous when synchronized by PRID was quit important compared with cows treated with prostaglandins, and varying between 72,73 and $87,5 \%$ with a better regrouping between 48 and $72 \mathrm{~h}$. We judged that the PRID ensures a good luteolysis effect and a decrease of circulating progesterone; witch gives a good rate of synchronization (Table 2). Also for the two processes, we have noted an ovulation rate varying between 75 to 87 , $5 \%$, and then concentrated between 48 and $96 \mathrm{~h}$. However there are a number of cows which ovulated without showing any sign of oestrous.

For Crestar protocols, ovulation diameters were compared with those observed by Smith and Stevenson (1995), of 15, $8 \pm 0,8 \mathrm{~mm}$. For the three groups treated with Crestar, heats were spread out over all the duration of this study, with rates of cows seen in heats varying from 40 to $66 \%$. We have even noted a number of cows which expressed behavioural heats, the day of implant withdrawal. The rate of cows presenting a CL the day of Crestar withdrawal, also varied from 20, 42, 86 and 55, 6\% for the 3 groups of Crestar treated cows (Table 2). On the other hand, we have noted for the two protocols (Crestar and prostaglandins) a rather significant rate of ovulation varying from 60 to $80 \%$, and concentrated between 48 and $72 \mathrm{~h}$. However, we have also noted that around of $40 \%$ of cows ovulates without showing any sign of oestrous Table 2 and 3 ).

Causes of luteolytic failure (occurring in $\geq 10 \%$ of prostaglandin treated cows) are not clear, but may be related to several factors (Peters and Ball, 1995).

The growth rate of largest follicles could also play an important role at the time of estrous and ovulation. The longer persisting progesterone concentration might influence the growth rate of the largest follicles and cause the failure of clinical sings of estrous and ovulation (Repasi et al., 2005).

\section{CONCLUSION}

Problems of estrous detection have to be resolved in dairy cows. Even after oestrous synchronisation, we have a number of cows witch do not respond to the treatment. This problem should be taken seriously by inseminators. Ignonrance of ovarian activity at the time of insemination involves a poor cow's fertility, and put the doubt in reproductive performance in dairy cows imported by our country. 


\section{REFERENCES}

Alexander, T.; Senger, J.P.L.; rosenberger, J.L. and Hagen, D.R. (1984): The influence of the stage of the estrous cycle and novel cows upon mounting activity of dairy cattle. J. Anim. Sci. 59: 1430- 1439.

Beal, W.E.; Good, G.A. and Peterson, L.A. (1983): Estrous synchronization and pregnancy rates in cyclic and non cyclic beef cows and heifers treated with synchro-mate B or norgestomet and alfaprostol. Theriogenology, 22: 59-66.

Brito, L.F.C.; Satrapa, R.; Marson, E.P. and ET Kastelic, J.P. (2002): Efficacy of PGF2a to synchronise estrous in water buffalo cows (bubalus bubalis) is dependent upon plasma progesterone concentration, corpus luteum size and ovarian follicular status before treatment. Elsevier Sci. Animal Rep. Sci. V73, 1-2, 23-35.

Britt, J.H. (1992): Impacts of early postpartum metabolism on follicular development and fertility. Proc. $24^{\text {th }}$ Annu. Conv; Am. Assoc. Bovine Pract. 24: 39 - 43.

Custer, E.E.; Beal, W.E.; Wilson, S.J.; Meadow, A.W.; Berardinel, J.G. and Adair, R. (1994): Effect of Melengestrol Acetate (MGA) or Progesterone-Releasing Intravaginal Device (PRID) on Follicular Development, Concentrations of Estradiol- 17P and Progesterone, and Luteinizing Hormone Release During an Artificially Lengthened Bovine Estrous Cycle.J. Anim. Sci. 72:1282-1289.

Driancourt, M.A. (2001): Regulation of ovarian follicular dynamics in farm animals' implications for manipulation of reproduction. Theriogenology, 55: 1211-123.

Ireland, J.J.; Mihm, M.; Austin, E.; Diskin, M.G. and Roche, J.F. (2000): Historical perspective of turnover of dominant follicles during the bovine estrous cycle: Key concepts, studies, advancements, and terms. J. Dairy Sci. 83: 1648-1658.

Kastelic, J.P.; KO, J.C.H. and Ginther, O.J. (1990): Suppression of dominant and subordinate ovarian follicles by a protei-naceous fraction of follicular fluid in heifers. Theriogenology 34 : 499-509.

Kastelic, J.P. and Ginther, O.J. (1991): Factors affecting the origin of the ovulatory follicle in heifers with induced luteolysis. Anim. Reprod. Sci. 26: 13-24. 
Larson, L.L. and Ball, P.J.H. (1992): Regulation of estrous cycle in dairy cattle: a review. Theriogenology 38: 255-267.

Lucy, M.C.; Billings, H.J.; Butler, W.R.; Ehnis, L.R.; Fields, M.J.; Kesler, D.J.; Kinders, J.E.; Mattos, R.C.; Short, R.E.; Thatcher, W.W.; Wettemann, R.P.; Yelich, J.V. and Hafs, H.D. (2001): Efficacy of an intravaginal progesterone insert and an injection of PGF $2 \alpha$ for synchronizing estrous and shortening the interval to pregnancy in postpartum beef cows, peripubertal beef heifers, and dairy heifers. J. Anim. Sci., 79: 982-995.

Lyimo, Z.C.; Nielen, M.; Ouweltjes, W.; Kruip, T.A.M. and Van Eerdenburg, (2000): Relationship among estradiol, cortisol and intensity of estrous behaviour in dairy cattle; Theriogenology 53: $1783-1795$.

Mapletoft, R.J.; Martı'nez, M.F.; Colazo, M.G. and Kastelic, J.P. (2003): The use of controlled internal drug release devices for the regulation of bovine reproduction J. Anim. Sci. 81 (E. Suppl. 2): E28-E36.

Mialot, J.P.; Laumonnier, G.; Ponsart, C.; Fauxpoint, H.; Barassin, E.; Ponter, A.A. and Deletang, F. (1999): Postpartum subestrous in dairy cows: comparison of treatment with prostaglandin F2alpha or GnRH + prostaglandins F2 alpha + GnRH. Theriogenology, 52: 901-911.

Odde, K.B. (1990): A review of synchronization of estrous in postpartum cattle. J. Anim. Sci. 68: 817-830.

Peters, A.R. and Ball, P.J.H. (1995): The Post Partum Period Reproduction in Cattle, $2^{\text {nd }}$ edition. Oxford, Blackwell Science, 145-160.

Rajamahendran, R. and Taylor, C. (1990): Characterization of ovarian activity in postpartum dairy cows using ultrasound imaging and progesterone profiles. Anim. Reprod. Sci. 22: 171-180.

Reimeirs, T.D.; Smith, R.D. and Newman, S.K. (1985): Management factors affecting reproductive performance of dairy cows in the northeastern United States. J. Dairy Sci. 68: 963-972.

Rèpàsi, A.; Beckers, J.F.; JSulon, A. Karen; Reicziget, J. and Szenci, O. (2005): Effect of the type and Number of Prostagandin treatments on corpus Luteum, the Largest Follicle and Progesterone Concentration in Dairy Cows. Repro. Dom. Anim. 40: 436 - 442. 
Sartori, R.; Rosa, G.J.M. and Wiltbank, M.C. (2002): Ovarian Structures and Circulating Steroids in Heifers and Lactating Cows in Summer and Lactating and Dry Cows in Winter. J. Dairy Sci. 85: 2813-2822.

Savio, J.D.; Thatcher, W.; Badinga, L. and De La Sota, R.L. (1990): Turnover of dominant ovarian follicles as regulated by progestin and dynamics of LH secretion in cattle. J. Reprod. Fertil. Abstr. Ser. 6: 23.

Sirois, J. and Fortune, J.E. (1988): Ovarian follicular dynamics during the estrous cycle in heifers monitored by real-time ultrasonography. Biol. Reprod. 39: 308-317.

Smith, M.W. et Stevenson, J.S. (1995): Fate of the Dominant Follicle, Embryonic Survival, and Pregnancy Rates in Dairy Cattle Treated with Prostaglandin F2a and Progestin in the Absence or Presence of a Functional Corpus Luteum. J. Anim. Sci. 73: 3743-3751.

Sprecher, D.J.; Nebel, R.L. and Whitman, S.S. (1989): The predictive value, sensitivity and specificity of palpation per rectum and transrectal ultrsonography for determination of corpora lutea status. Theriogenology 31: 1165-1172.

Van Eerdenburg, F.J.C.M.; Karthaus, D.; Taverne, M.A.M; Merics, T.I. and Szencit, O. (2002): The Relationship between Estrous Behavioural Score and Time of Ovulation in Dairy Cattle. J. Dairy Sci. 85: 1150-1156. 